plicated hiatal hernias. Endoskopicheskaya hirurgiya. 2016;22(2):14-17

12. Tam V., Winger D. G., Nason K. S. A systematic review and meta-analysis of mesh versus suture cruroplasty in laparoscopic large hiatal hernia repair. Am. J. Surg. 2016;211(1):226-238

https://doi.org/10.1016/j.amjsurg.2015.07.007
13. Cherkasov M. F., Startsev Yu. M., Cherkasov D. M. Abdominal'naya hirurgiya. Nacional'noe rukovodstvo: kratkoe izdanie. Pod red. I.I. Zatevahina, A. I. Kirienko, V. A. Kubyshkina. M.: GEOTAR-Media; 2016

14. Chernousov A. F., Horobryh T. V., Vetshev F. P. Repeated antireflux surgery. Vestnik hirurgicheskoj gastroenterologii. $2011 ; 3: 4-15$

\begin{abstract}
About authors:
(C) Trushin P. V., 2019

UDC 617-089.844:546.82-034.24-19

DOI - https://doi.org/10.14300/mnnc.2019.14114

ISSN - 2073-8137
\end{abstract}

Cherkasov Denis Mihajlovich, MD, PhD, Associate Professor of the Department of surgical diseases № 2 ; tel.: +79185003275; e-mail: doctor1012@ramblerl.ru; ORCID - 0000-0003-0320-7923

Cherkasov Mihail Fedorovich, MD, PhD, Professor, Head of the Department of surgical diseases; tel.: +79188923200; e-mail: cherkasovmf@mail.ru; ORCID - 0000-0001-7587-8406

Tat'yanchenko Vladimir Konstantinovich, MD, PhD, Professor, Head of the Department of operative surgery, clinical anatomy and pathological anatomy; tel.: +79185010595; e-mail: vladimirtatyanchenko@mail.ru; ORCID - 0000-0002-7407-2686

Melikova Sabina Gadzhievna, senior laboratory assistant of the Department of surgical diseases; tel.: +79185155832; e-mail: sarbonka@bk.ru; ORCID - 0000-0002-1966-1664

Starcev Yurij Mihajlovich, PhD, Associate Professor of the Department of surgical diseases; tel.: +79289541816; e-mail: starcevvv111@mail.ru; ORCID - 0000-0002-5769-4598

Shamik Viktor Borisovich, DMSc, Professor, Professor of the Department of pediatric surgery and orthopedics; tel.: +79188923200; e-mail: prof.shamik@gmail.com; ORCID - 0000-0002-0461-8700

\title{
APPLICATION OF FINELY GRANULATED TITANIUM NICKELIDE IN SURGICAL PRACTICE
}

Trushin P. V.

\author{
Novosibirsk State Medical University, Russian Federation
}

\section{ПРИМЕНЕНИЕ МЕАКОГРАНУАИРОВАННОГО НИКЕАИАА ТИТАНА В ХИРУРГИЧЕСКОЙ ПРАКТИКЕ}

\section{П. В. Трушин}

\section{Новосибирский госуАарственный меАицинский университет, Российская ФеАерация}

A clinical study involved 90 patients with chronic osteomyelitis. Patients were divided into two groups. In group I, 60 patients underwent sequestrectomy and plastic surgery of the sequestral cavity with finely granulated titanium nickelide. In group II, 30 patients after sequestrectomy, the bone cavity was filled in the traditional way (hemoplasty). Both in the early postoperative period and the long follow-up period, the clinical and radiological effects of the proposed methodology for treating residual bone cavities were confirmed. When using titanium nickelide implants, the formation of biocomposite is observed in patients, which ensures the preservation of bone strength. This prevents the occurrence of pathological fractures. Titanium nicelide is characterized by mechanical strength, has osteoconductive properties and allows sufficient filling of cavities with complex anatomical structure. Also, preservation of congruence of composite with bone tissue during bone growth (in case of treatment of children) is noted.

Keywords: dystrophic bone cysts, chronic osteomyelitis, plasty, titanium nickelide

В клиническом исследовании участвовали 90 пациентов с хроническим остеомиелитом. Пациенты были разделены на 2 группы. В группе I у 60 пациентов выполнялась секвестрэктомия и пластика секвестральной полости мелкогранулированным никелидом титана. В группе II у 30 пациентов после секвестрэктомии костная полость заполнялась традиционным способом (гемопломбой). Как в раннем послеоперационном периоде, так и в отдаленном периоде наблюдения подтверждается клинико-рентгенологическая эффективность предлагаемой методики лечения остаточных костных полостей. При использовании имплантатов из никелида титана наблюдается формирование у пациентов биокомпозита, который обеспечивает сохранение прочности кости. Это предотвращает возникновение у больных патологических переломов. Никелид титана отличается механической прочностью, обладает остеокондуктивными свойствами и позволяет эффективно заполнять полости, имеющие сложную анатомическую структуру. Помимо этого, отмечено сохранение конгруэнтности композита с костной тканью в процессе роста кости (в случае проведения лечения детей).

Ключевые слова: дистрофические костные кисты, хронический остеомиелит, пластика, никелид титана 
For citation: Trushin P. V. APPLICATION OF FINELY GRANULATED TITANIUM NICKELIDE IN SURGICAL PRACTICE Medical News of North Caucasus. 2019;14(3):472-475. DOI - https://doi.org/10.14300/mnnc.2019.14114

Для цитирования: ТрУшин П. В. ПРИМЕНЕНИЕ МЕЛКОГРАНУЛИРОВАННОГО НИКЕЛИДА ТИТАНА В ХИРУРГИЧЕСКОЙ ПРАКТИКЕ. Медицинский вестник Северного Кавказа. 2019;14(3):472-475.

DOI - https://doi.org/10.14300/mnnc.2019.14114

ChO - chronic osteomyelitis

U ndoubtedly, in the surgical treatment of skeletal and joint disorders, the result mainly depends on the skill of the surgeon, as well as the subsequent rehabilitation. However, technological equipment is equally essential for a favorable outcome. The use of implants made of nickel and titanium became a new milestone in the treatment of bone pathologies. Their advantage is high biocompatibility, as well as a maximum approximation of mechanical characteristics to the properties of bone tissue [1]. In addition to bioinertia (biochemical compatibility) and similarity with bone tissue in terms of physical and mechanical properties, titanium nickelide implants have some advantages. The main ones are the following: corrosion resistance, lack of toxicity or carcinogenicity, easy sterilization, ability to provide the necessary porosity of the structure, wettability, and permeability. The ease of germination of living tissues in the pores of titanium nickelide was also noted, which provides the formation of a direct connection between the implant and bone [2-6]. However, today, as a rule, homo- or autografts are used as a plastic material [7]. However, in the case of transplantation of biological tissues the efficiency of reconstructive surgeries can be significantly reduced as compared to the expected effect due to the high intensity of resorption [8, 9]. This leads to the resorption of the graft in the body before restoration of the lost or corrected bone segment.

The purpose of the study was to an assessment of the effects of fine-granulated titanium nickelide for the plasty in the patients with $\mathrm{ChO}$.

Material and Methods. Ninety patients (67 men and 23 women) with $\mathrm{ChO}$ were followed-up. The age of patients ranged from 16 to 60 years (average age was 37.1 years). Patients divided into two groups. The group I included 60 patients whom finely granulated titanium nickelide was used to fill the bone cavity after sequestrectomy. The group II included the remaining 30 individuals, in whom the traditional method was used to fill the bone cavity (blood tap) after sequestrectomy. One or more sequestral cavities were found in study participants with ChO (Table).

Table

Localization of the $\mathrm{ChO}$ in the bones

\begin{tabular}{|l|c|c|c|c|}
\hline \multirow{2}{*}{$\begin{array}{c}\text { Name of bone } \\
\text { with ChO }\end{array}$} & \multicolumn{2}{c|}{$\begin{array}{c}\text { Group I } \\
(\mathrm{n}=60)\end{array}$} & \multicolumn{2}{c|}{$\begin{array}{c}\text { Group II } \\
(\mathrm{n}=30)\end{array}$} \\
\cline { 2 - 5 } & Abs & $\%$ & Abs & $\%$ \\
\hline Ankle bone & 2 & 3.3 & 3 & 10 \\
\hline Distal phalanges & 2 & 3.3 & 0 & 0 \\
\hline Fibula & 2 & 3.3 & 3 & 10.0 \\
\hline Heel bone & 4 & 6.7 & 2 & 6.7 \\
\hline Humerus & 5 & 8.3 & 2 & 6.7 \\
\hline Radial bone & 2 & 3.3 & 1 & 3.3 \\
\hline Tibia & 21 & 35.0 & 12 & 40.0 \\
\hline Thigh & 22 & 36.7 & 7 & 23.3 \\
\hline
\end{tabular}

Disease duration ranged from 6 months to 13 years. Patients with complications at the background of the underlying diseases were excluded from the study. Specifically, they included individuals in whom disease course was complicated by unconsolidated fracture or formation of a false joint. The composition of the groups was planned, so the groups were similar in the gender of the patients, their age, localization and duration of the pathological process, and the number of previous surgeries. This was necessary to ensure the reliability of the results. The clinical form of $\mathrm{ChO}$ was confirmed in each of the participants. $76.7 \%$ of patients (69) suffered from post-traumatic ChO, the remaining $23.3 \%$ (21) had hematogenic osteomyelitis. In $7.8 \%$ patients (5), post-traumatic osteomyelitis developed due to incorrect treatment of local infectious disorders. 2 patients with hematogenic $\mathrm{ChO}$ did not receive surgical treatment before. Other research participants had previously undergone surgical treatment due to complications. In the analyses of $80 \%$ patients different bacterial cultures were isolated: $72.2 \%(52)$ - Staphylococcus aureus, $12.5 \%$ (9) - Streptococcus haemolyticus, $6.9 \%$ (5) - mixed flora (Streptococcus pyogenes+Enterococcus faecalis), $4.2 \%$ (3) - Pseudomonas aeruginosa, and $4.2 \%$ (3) E. coli. All patients underwent conservative treatment, up to obtaining negative results of culture and the absence of inflammation factors in the wound discharge. Sixty patients in the group I received surgical treatment with new approach. The surgery involved simultaneous plastic replacement of residual bone cavities at a surgical clinic. During the surgical dissection of fistula, sequestrectomy and bone cavities plasty with titanium nickelide were performed. In the case of emergency admission due to the phlegmons, preliminary treatment during 8-10 days was required. During this period, incision, draining, and sanation of phlegmons were performed. Subsequently, sequestrectomy and plasty with fine-granulated titanium nickelide were performed. At the initial stage of the surgery, the fistulous tracts were isolated and cut to the bone; the altered periosteum was removed, sequestral box was incised with removal of sequestration with granulation tissues (Fig. 1). Then thorough cavity curettage was performed before the appearance of the phenomenon of "pinpoint bleeding" from the lumen of the cavity. It is necessary to activate osteogenesis.

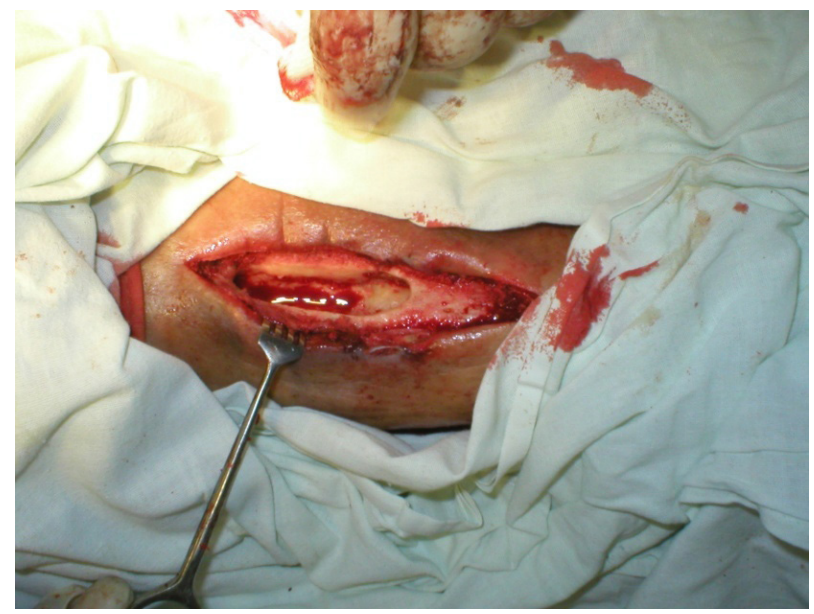

Fig. 1. Tibia with the resected sequester

Subsequently, the sequester's cavity was filled with sterile dry microgranules of titanium nickelide after 
preliminary rinsing with antiseptic solutions. The amount of implant required for plasty should be not less than $1 / 3$ of the bone cavity volume (Fig. 2)

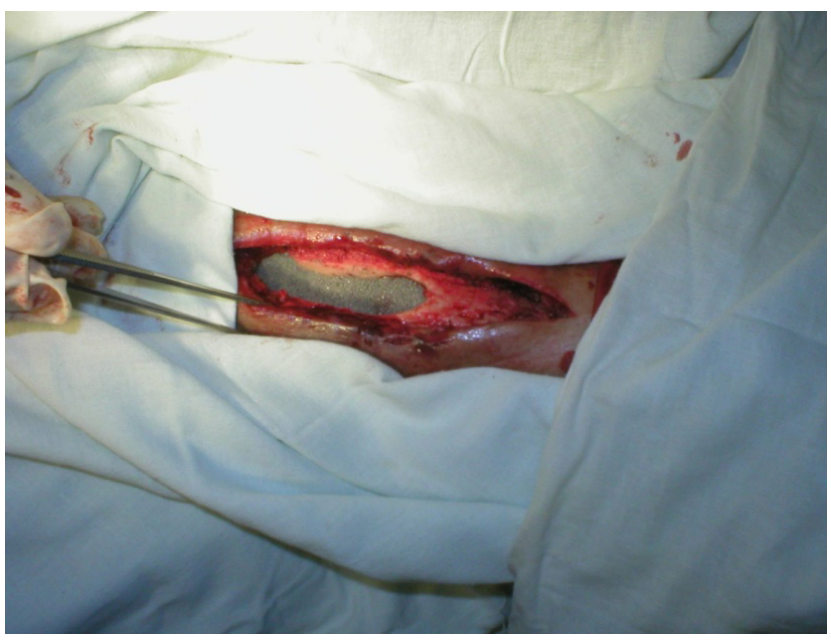

Fig. 2. The sequester's cavity filled with titanium nickelide granules

At the end of the surgery, the wound was sutured (tightly) with the rubber drainage left for one day. Postoperative management of patients included a 5-day course of antibiotic therapy (Ceftriaxone, Cephatoxin), regular wound dressings, and physiotherapy. The operated limb was immobilized in a physiological position using a plaster bandage for six weeks. Sutures were removed after ten days.

Variation statistics processed data according to Fischer-Student in Statistics 6.0 (StatSoft, USA). Differences were considered significant at $p<0.05$.

Results and Discussion. The particular interest is the results of the analysis of the postoperative period in patients of both groups. It was noted that during the assessment of the condition on the 5th day after surgery such signs as edema in the area of surgical intervention and pain in the sutured wound in patients from the group I were less frequent vs. patients in the group II. They were noted in $74.1 \%$ and $58.8 \%$ of patients of the group I, respectively, vs. $89.3 \%$ and $85.7 \%$ in group $\mathrm{II}(\mathrm{p}<0.05)$ The occurrence of complications in the early postoperative period in the group I was also slightly lower than in the comparison group. Suppuration of postoperative wound occurred in $6.7 \%$ subjects $(n=4)$ in the group I versus $13.2 \%(n=4)$ subjects in the group II; $3.3 \%(n=2)$ subjects in each group had hematomas in the area of postoperative wound; and also wound edge necrosis developed in $10 \%(n=3)$ subjects in the group II. The manifestation of postoperative complications was caused by a widespread defect of tissues, which occurred even before the surgery. The lack of tissue to close the defect was due to the resection of the scar edges of the wound. Complications were eliminated after the revision of the fistula, as well as after the appropriate drug therapy. The condition of all patients at discharge was satisfactory. It is noteworthy that in the group I healing with primary intention was more common than in group II. In the group I, it was observed in $92 \%$ subjects $(n=55)$, and in group II - in $70 \%(n=21)$ subjects. Besides, the average duration of hospital stay in the group I was shorter than in group II. It was 11.6 patientdays in case of scheduled surgery and 17.7 patient-days after emergency intervention in the group I vs. 14.8 and 23.6 patient-days in the group II, respectively. Follow-up for control of long-term outcomes was carried out over the period from 4 months to 5 years after surgery. The result of treatment in patients from the group I was better than in patients from group II. Thus, all participants in the group I noted the absence of pain in the operated limbs; on palpation, a smooth and dense bone surface was found. Fistula in the area adjacent to the postoperative suture was detected in $5 \%$ of subjects $(n=3)$. In group II, $13.3 \%$ subjects $(n=4)$ complained of regular pain in the operated limbs; in $16.7 \%(n=5)$ subjects, fistulae were found, and also swelling of soft tissues was noted in the same number of patients. X-ray examination showed signs of bone regeneration in patients of both groups. However, in the group I this process was much more active than in group II. Thus, all patients of the group I had a periostal bone reaction in the area of destruction, whereas in group II it was found only in $42.1 \%$ subjects $(n=24)$. The endosteal response was observed in $40.3 \%$ subjects $(n=23)$ in group I versus $35.7 \%(n=10)$ in group II. The difference in treatment outcomes in patients from the groups was significant. An X-ray performed one month after the surgery showed that in all patients from the group I had shadows of implant materials with unclear contours in the area of the corrected bone lesions. Over time, the intensity of the darkness increased starting from the edges of the defect. Six months after the surgery, the findings obtained during the examination corresponded to healthy bone tissue and did not change in future (Fig. 3).

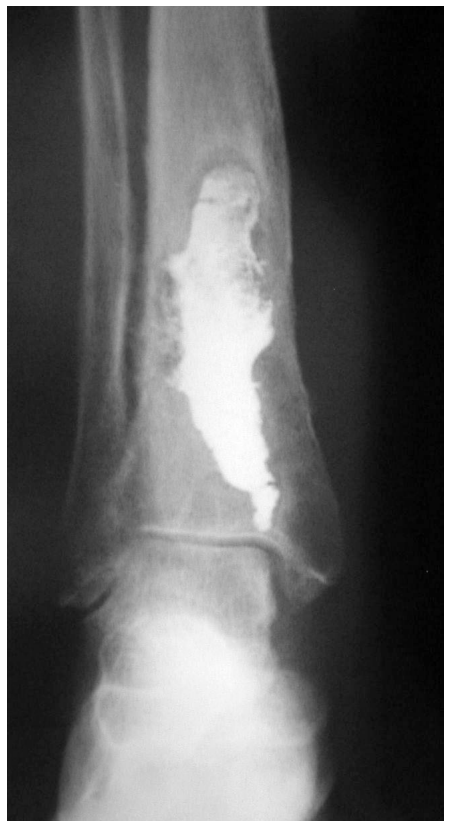

Fig. 3. X-ray of the tibia six months after sequester's cavity plastic with fine-granulated titanium nickelide

None of the patients in group II had a complete obliteration of the bone cavity after the same time. The number of relapses of $\mathrm{ChO}$ in the long-term follow-up in the group I did not have, in group II $-10.7 \%(n=3)$. The results of the surgical treatment performed with titanium nickelide, as well as the cosmetic effect, can be characterized as good. Complete restoration of the functions of the operated limbs has been achieved. Based on clinical experience, it can be concluded that the treatment of $\mathrm{ChO}$ using sequestrectomy with cavities plasty with finely granulated titanium nickelide allows achieving more favorable outcomes vs. traditional methods. At the same time, small traumatism and simplicity of the new approach should be noted. Its use has some advantages. The main advantages include reduction of the number of postoperative complications, as well as unfavorable longterm outcomes; reduction of the number of relapses; shorter hospital stay; restoration of bone defects in a 
shorter period; improvement of the quality of life of the patients.

Conclusions. The results of the experimental studies confirmed good prospectivity and high potential of the use of finely granulated porous titanium nickelide as an implant for the treatment of ChO. Filling bone cavities with biocompatible porous titanium nickelide in the form of microgranules in the surgical treatment of $\mathrm{ChO}$ had several advantages. The main ones are the following: faster and more effective resolution of inflammatory processes in the bone tissue, comparative simplicity of the technique and shorter duration of surgery, reduced length of inpatient treatment, and rehabilitation.
When using titanium nickelide implants, the formation of biocomposite is observed in patients, which ensures the preservation of bone strength. This prevents the occurrence of pathological fractures. Titanium nicelide is characterized by mechanical strength, has osteoconductive properties and allows effective filling of cavities with complex anatomical structure. Also, preservation of congruence of composite with bone tissue during bone growth (in case of treatment of children) is noted. The use of titanium nickelide implants significantly increases the quality of life of patients and reduces the likelihood of disability.

Disclosures:

The author declares no conflict of interest.

\section{References}

1. Iriyanov Y. M., Chernov V. F., Radchenko S. A., Chernov A. V. Plastic efficiency of different implants used for repair of soft and bone tissue defects. Bull. Exp. Biol. Med. 2013;155(4):518-521. https://doi.org/10.1007/s10517-013-2191-4

2. Biocompatible materials with shape memory and new technologies in medicine. Ed. Gunther V. E. Tomsk: Publishing company «MIC RDE», 2014.

3. Iryanov Yu. M., Strelkov N. S., Kiryanov N. A., Dyuryagina O. V. Treatment of cavitary bone defects under implantation of the mesh structures made of titanium nickelide. Medical News of North Caucasus. 2017;12(2):152-156. https://doi.org/10.14300/mnnc.2017.12043

4. Klimovitsky V. G., Zhilitsyn Ye. V. Treatment of bone cysts of different localization in children. Trauma. 2012;13(3):7-10.

5. Shtofin A. S., Shegolev M. B., Trushin P. V., Golovnev V. A., Golovnev A. V. [et al.] Application of porous titanium nic- kelide for treatment of patients with chronic osteomyelitis Medical News of North Caucasus. 2017;12(3):281-284. https://doi.org/10.14300/mnnc.2017.12098

6. Sirak S. V., Giesenhagen B., Koshel I. V., Schau I., Shchetinin E. V. [et al.] Osteogenic Potential of Porous Titanium. An Experimental Study in Sheep. Journal of the National Medical Association. 2019;111(3):310319. https://doi.org/10.1016/j.jnma.2018.11.03

7. Radkevich A. A., Khodorenko V. N., Gunter V. E. Reparative osteogenesis in bone defects after substitution with finely granulated porous titanium nickelide. Implants with shape memory. 2005;(1-2):30-34.

8. Khodorenko V. N., Monogenov A. N., Gunter V. E. Permeability of medical titanium nickelide based porous alloys. International conference "New materials in medicine». Krasnoyarsk, 2000.

9. Fomichev N. G. New technologies in spinal surgery using implants with shape memory. Tomsk, 2002

\title{
About author
}

Trushin Pavel Victorovich, CMSc, MD, Associate Professor of the Department of hospital and children's surgery; tel.: +79039038682; e-mail: tpv1974@rambler.ru

\section{THE EFFECT OF OXIDATIVE STRESS ON SEMEN QUALITY. PATHOGENETIC ASPECTS}

\author{
Sturov N. V. ${ }^{1}$, Pashina N. R. ${ }^{2}$, Ryzhakin S. M. ${ }^{1}$, Korovyakova E. A. ${ }^{1}$, \\ Karaseva N. V. ', Pashin S. S. ${ }^{2}$, Barkhudarov A. A. ' , Druzhinina N. K. ${ }^{1}$ \\ ${ }^{1}$ Peoples' Friendship University of Russia (RUDN University), Moscow, Russian Federation \\ 2 I. M. Sechenov First Moscow State Medical University (Sechenov University), \\ Moscow, Russian Federation
}

\section{ОКСИААТИВНЫЙ СТРЕСС ПРИ ПАТОСПЕРМИИ. ПАТОГЕНЕТИЧЕСКИЕ АСПЕКТЫ}

\author{
Н. В. Стуров ${ }^{1}$, Н. Р. Пашина ${ }^{2}$, С. М. Рыжакин ${ }^{1}$, Э. А. Коровякова ${ }^{1}$, \\ Н. В. Карасева ${ }^{1}$, С. С. Пашин ${ }^{2}$, А. А. Бархуааров ${ }^{1}$, Н. К. Аружинина ${ }^{1}$ \\ 1 Российский университет Аружбы народов, Москва, Российская ФеАерация \\ 2 Первый Московский госУАарственный МеАицинский университет \\ им. И. М. Сеченова (Сеченовский Университет), Москва, Российская ФеАерация
}

It is known that one of the main pathogenetic mechanisms of male infertility is increasing the level of reactive oxygen species (ROS) in the ejaculate. Thereby identify of pathogenetic factors of oxidative stress in pathospermia is very actually. A retrospective analysis of 230 men with poor semen quality (according to criteria of semen, WHO 2010) and increased ROS 